\title{
Training the Employee for Improved Performance: the Mediating Role of Employee Performance Appraisal
}

\author{
Article by Freda Kabuki Ocansey \\ Ph.D. in Management, Texila American University, Ghana \\ E-mail:fredaocansey@yahoo.co.uk
}

\begin{abstract}
Training employees has big implications on time and money for businesses; yet businesses cannot do without training because businesses at all times need human resource with the requisite knowledge, skills and ability to perform to ensure productivity. How are organisations ensuring that knowledge and skills acquired from training are well transferred into job performance? The study sought to examine the seemingly inability of some employees who undergo training to transfer the competencies they acquire from training into the performance of their job functions by exploring the extent to which the employee is involved in decisions regarding his or her training and how organizations are making use of strategies and interventions to ensure that the expected transfer of knowledge and skills is achieved to ensure the expected performance. A case study design and purposive sampling were adopted to select 58 employees who had attended training in the last 24 months from 5 institutions in the Ada West district of the Greater Accra Region of Ghana. Data was collected by using 52 fully completed questionnaire. Data was analysed by using descriptive statistics. The results indicate that the full involvement of employees in assessing gaps in their performance would make them appreciate better, training programmes they attend. Also in order for employees to fully commit to training they attend, they should also be involved in choosing when to attend training. Post training mentoring, monitoring, evaluation, continuous coaching and encouragement, appropriate follow-up training programmes, unbiased, objective, wellstructured and regular employee appraisals are identified as effective ways of ensuring the gradual assimilation and consequent transfer of taught competencies into performance.
\end{abstract}

Keywords: Employee performance appraisal, employee training, transfer of taught competencies, employee performance, organizational productivity

\section{Background to the study}

The intense competitiveness amongst organizations the world over has made organizational productivity an essential tool for continuous survival and wellbeing. For an organization to survive and for it to chalk successes, it needs a workforce that has the capability of achieving at all times. Employee performance must be of prime concern of every organization that wishes to succeed and many organizations have identified training of its employees as one of the strategies for ensuring the needed improved employee performance. China Gorman (CEO at Great Places to Work) says that, "as companies grow and the war for talents intensifies, it has become increasingly important that training and development programs are not only competitive but are supporting the organization on its defined strategic path”. Organizations are therefore seeking to develop strategic training and development policies all aimed at improving the competencies of employees for the effective performance of job functions (Noe 2005). Bernadin (2003) and Harris (2000) describe training as formal attempts at correcting identified flaws in job performance competencies of the employee. Beer, Finnstrom, Schrader, (2016) say in their article "Why Leadership Training Fails and What to do about it" that American companies spend huge amounts of funds on the training and education of their employees. They cite approximate amount of money spent on employee training and education for the year 2015 alone as 160 billion dollars for America alone and about 356 billion dollars for the entire world. This notwithstanding, organizations 
continue to grapple with employee performance challenges. Beer, Finnstrom, Schrader (2016) affirm that organizations are not getting the expected results on their investment in employee education and training. Many have researched on why training has not brought in the expected results of improved performance of the employee. Writers such as Fleming (2016), Latham (2013) and Tschol (2014) have published articles on why training fails. They all cite factors such as irrelevancy of training to the needs of trainees, ill prepared and inexperienced trainers, poorly developed training programs, stupid and irrelevant games during training, large training groups which make group discussions and the assurance of individual participation ineffective and also complicated and/or insufficient training materials. Fleming (2016) however raises amongst his perceived list of reasons why training programs fail, a core problem that most organisations must devote their attention to; the failure of reinforcement of taught competencies. Behavioural change are the most difficult to achieve and training the employee for improved skills, attitudes and competencies is just that. What should organizations do to ensure the desired change after training? Planned personal coaching and support are very much necessary. Fleming (2016) recommends "a strong framework of goal setting and a two-way feedback, if not 360 feedback". For skills development to succeed, according to him, "coaching of a different kind" is necessary. There should be a lot of demonstration and practice in an environment where learners are encouraged to practice without fear of making mistakes and being reprimanded. Employees should be given that opportunity to learn from their mistakes with the encouragement of learning from these mistakes. Immediately after training, the employee must be placed in the situation where he or she can practice what he or she has learnt under guidance. Fleming (2016) sees this as the work of managers who themselves must be trained to play this role effectively. Our attention is drawn to performance appraisal, a useful management tool. If organizations are spending so much on training, they must see ultimate results in the form of improved productivity. If this is not happening, Fleming (2016) is saying that a strong and well planned appraisal system should be put in place, to foster the expected results.

\section{Statement of the problem}

Organizational efficiency and effectiveness have everything to do with the quality of its human resource. The enhancement of the capabilities and performance of the employees should be of prime importance to any organization which seeks to succeed in its operations. It is to this effect that most organizations commit funds in their annual budgets for employee training. The expectation is that training would bring the needed improvement in the job performance of employees. However, training without the expected transfer of acquired competencies into job performance is a problem most organizations are faced with. Even though many researchers have come out with various solutions to the problem, this challenge is found to persist in most organizations.

\section{Purpose of the study}

This study seeks to place emphasis on the role of employee performance appraisal in the performance development of the employee. The researcher believes that the active involvement of the employee from the beginning of the process of identifying his or her training needs to the final stage of providing continuous post-training mentoring, monitoring and evaluation of the performance of the employee will afford the employee who may not have fully understood and mastered the competencies he or she had been taught during the usually limited training period, the opportunity to learn over an extended period of time through guided practice.

\section{Research questions}

The research sought answers to the following questions

1. To what extent are employees involved in identifying their training needs?

2. Is the employee involved in the decision on when to go on training? 
3. What factors account for the inability of the trainee to integrate and transfer competencies they learn into their job functions?

4. Would post-training mentoring, monitoring and evaluation and follow-up training help the employee master newly learnt competencies such that they can transfer them (newly acquired competencies) into the performance of their jobs?

\section{Significance of the study}

Most organizations are devoting a lot of money and valuable working hours to ensure the improvement of their work force. Expected results are not seen primarily because most employees who undergo training are unable to integrate and transfer competencies they learn into practice at their job places. Researchers have proposed as solution, needs assessment of employees before they are nominated for training, teaching methods and job performance evaluation after training. This study goes further to encourage organizations to lay more emphasis on the full involvement of the employee inidentifying and appreciating his or her training needs, identifying appropriate training for him or her and deciding on when he or she should go on training. It is the researcher's belief that employees would be more committed to learning and integrating what they are taught if they appreciate the short-comings in their competencies; they would be more open to fully participating in strategies to help them overcome their inadequacies and improve on their performance. More importantly, the study seeks to emphasise the need for employees who are unable to perform as required after going through training to be guided through coaching and mentoring over an extended period to enable them perform as expected.

\section{Review of related literature}

Employee performance and organizational productivity.

Employees are the backbone of every organisation. Whether or not the organization achieves its strategic corporate objectives, depends largely on the skills and knowledge and the willingness of its employees to perform. Organizations adopt various strategies to compete for survival and supremacy over its competitors. According to Beard well et al (1997), due to these competitive pressures, organizations are continually looking to increase the added value of their employees by encouraging them to increase their effort and performance. In other words, organizational efficiency and effectiveness largely rest on the quality of its workforce, that is, its human resource. Mayhew (1967) also affirms that the success of every organization or business rests on its employees' performance at their given functions. She says without mincing words that poor job performance of employees is detrimental to the company's success. This explains why organizations all over the world are doing all they can to ensure their employees attain maximum performance level and are very efficient and effective in their job output. Issues that relate to the enhancement of the capabilities and performance of the employee should therefore be of concern to the organization, and it is simply because on these rest the efficiency and effectiveness of the organization. As Puckett (2015) puts it, 'a talented and skilled workforce is the lifeblood of every organization and as the war for talent escalates, companies are quickly learning the importance of having the right people' with the right skills, attitudes and competencies to sustain the organization, ensure it remains in business and is indeed successful. A successful organization is one that achieves acceptable levels of productivity through the attainment of its mission or goals through the successful achievement of its strategic corporate objectives. Employee performance is so important to organizational success that Puckett (2015) mentions among the top three challenges she thinks organizations currently face 'the need to revamp and improve employee learning'. Sullivan (2011) agrees to this assertion. Based on his over thirty years of observational research into the success behind high performing businesses, he identifies twenty-two factors of a high performance business. The first among these is what he describes as 'high-performing and innovative employees'. He simply concludes that they are the very foundation, the very rock on which productivity lies. The question we should be 
Texila International Journal of Management

Volume 2, Issue 2, Dec 2016

asking ourselves is how do organizations ensure their employees are performing? Is training the key?

Why train the employee?

Can businesses do without employee training? The cost would be dire indeed; the organization would have employees who are inefficient, without confidence and unhappy; organizational productivity would be low, time and money would be lost due to mistakes and the organization would eventually lose its customers (Benton, 2014). Benton (2014) begins his article with a very illustrative question; he asks - if you were to choose between two different pilots to fly you and your family over the Atlantic Ocean, for example, which one would you choose, the trained pilot or the untrained one? Assume that you do not pay anything at all for the untrained to fly you, would you choose the untrained pilot? If you value your life and that of your family, you would definitely choose the trained pilot. It therefore goes to say, that businesses that value effectiveness and efficiency to achieve maximum performance and productivity, must seek training for their employees. Frost (2007) sees employee training as a vital opportunity for businesses to expand the knowledge base of their employees. She however laments that many employers find this opportunity expensive and a waste of precious working time and so they disregard it. She insists that despite the potential inconveniences and costs associated with the training and development of the employee, both the company and the employee would enjoy benefits which make the cost and associated inconveniences that training the employee bring a worthwhile investment. Enablingchange.co.uk (2013) says training is the best way of expanding the knowledge base of employees, even though most organizations find it expensive and time wasting. Well planned training and development programs are effective in providing businesses and their employees with 'benefits that would make investing worthwhile' (enablingchange.co.uk, 2013). Well planned training ensures return on investment (ROI).

\section{Why training fails}

It is reported that in the year 2000, the Association of Talent Development conducted a study which reported that $95 \%$ of training programs attained a level where trainees said they liked the training; however only $37 \%$ of training programs saw trainees admit they learned the material. An abysmal 13\% of training programs reached the level of participants saying they were able to apply what they have learnt at the workplace and only $3 \%$ of training programs actually had an impact on organizations (Fleming, 2016). Bacal and Associates (2015) also say that even organizations which believe in committing funds to train the employee, experience loss of investment returns on funds and time spent on training employees. This assertion is further confirmed by Beer, Finnstrom and Schrader (2016) who say that organizations have become victims of the 'great training robbery'. They explain that even though American companies spend billions of dollars on training, they are not seeing the expected results. Companies are not seeing better performance primarily because employees who receive training quickly revert to the old ways of going about their duties. Latham (2013) explains that it is difficult to achieve positive results, if one does not even know what one is supposed to do. Not determining if training is the best method to achieve the desired changes is a sure way to miss the benefits of training (Sinha, 2007). Many other reasons have been advanced to explain why training fails. The lack of proper identification and specification of learning objectives and outcomes, trainees not actively involved in the development of the learning program and the lack of commitment of management by providing continued support (Sinha, 2007). John Tschol (2014) mentions boring training, large groups of trainees, complicated training materials and irrelevant information. Spitzer (1984) thinks that viewing training as education and also as a fringe benefit are some of the reasons why training fails. However, Fleming (2016) identifies three simple reasons for the failure of training; poor training development, poor or no trainer training and lastly failure to reinforce for the desired change.

The mediating role of employee performance appraisal 
One of the most important tools management of businesses use to assess the performance of their workforce is performance appraisal. Mote (2010) describes performance appraisal as the process by which organizations evaluate employee performance based on pre-set standards. Archer and Associates say performance appraisal offers the valuable opportunity of focusing on work activities, goals and objectives, identifying and correcting of existing problems and encouraging better future performance. The impact of successfully appraising the performance of every individual employee of the organization reflects in the enhancement of the performance of the organizations as a whole. Mote (2010) says that if appraisal is done correctly, employees are led to improve upon their job performance, appropriate goals are set for employees and managers learn how to assess their subordinates' effectiveness such that they can take appropriate actions related to training, compensation, promotion, job design transfers etc. It therefore goes without saying that employee appraisal does have a vital role to play in guiding the performance of the employee. The manager who regularly appraises or assesses his subordinates against set goals, works with them to unearth existing shortfalls or gaps in their performance and together they agree on how these problems can be solved. Training is one of the remedies to such identified shortfalls in performance. And it is expected that employees would transfer what he learns into his job performance. Frieson et al (2009) lists the first barrier to the transfer of training as the lack of continuous support and reinforcement on the job. Also listed are the trainees, perception of the impractical training and also it irrelevancy. These key barriers are overcome with successful employee appraisal at the work place.

\section{Methodology}

This research adopted the descriptive survey design. The target population was employees who had attended training in the last 24 months from 5 institutions in the Ada West district of the Greater Accra Region of Ghana. The purposive sampling method was used to select a total58 employees. These comprised employees at three pre-determined levels for the study: senior management (Heads of the institutions and heads of departments), middle level officers (secretaries to heads, front desk officers and other middle level officers), junior officers (drivers, cleaners, office assistants). A questionnaire was used as the sole instrument for data collection. 52 completed questionnaire were used for the analysis.

Table 1 Distribution of target population and sample

\begin{tabular}{llll}
\hline Group & Target population & Sample size & Percentage \\
\hline Senior management & 28 & 11 & 39.3 \\
Middle level officers & 86 & 35 & 40.7 \\
Junior officers & 18 & 6 & 33.3 \\
\hline Total & 132 & 52 & 39.4 \\
\hline
\end{tabular}

\section{Results and discussion}

Descriptive statistics were used to analyse data. The data that was collected was grouped under the four main objectives of the study and these were: the extent of employees' involvement in the kind of training he should attend and when he or she should go on training; and finally whether they think the organization is doing enough to help them effectively transfer taught competencies into effective practice for the achievement of the expected improvement in the work roles. 
Texila International Journal of Management

Volume 2, Issue 2, Dec 2016

Table 2 Summary of responses on employees' involvement in determining training needs

\begin{tabular}{lll}
\hline Rate of involvement & Frequency & Percentage \\
\hline Very high & 6 & 11.54 \\
High & 4 & 07.69 \\
Average & 11 & 21.15 \\
Below average & 19 & 36.53 \\
Not involved at all & 12 & 23.07 \\
\hline Total & 52 & 99.98 \\
\hline
\end{tabular}

A close study of responses to whether or not employees are involved in deciding on which training they attend indicate that more than $50 \%$ of the respondents said they are hardly consulted when it comes to taking that crucial decision of sending them for training. One of the reasons why training fails to achieve the desired effect of transforming the work behaviour of the trainee is the lack of appreciation of his or her the need to change and his or her subsequent willingness to receive training for the needed change. If the trainee is not consulted and is ordered to go on training, he is likely to return from training without having learnt anything at all. Involving the trainee in planning for his training ensures his commitment.

Table 3 Summary of responses on employees' involvement in determining when to go on training

\begin{tabular}{lll}
\hline Rate of involvement & Frequency & Percentage \\
\hline Very high & $\mathbf{1 3}$ & $\mathbf{2 5 . 0}$ \\
High & $\mathbf{6}$ & $\mathbf{1 1 . 5}$ \\
Average & $\mathbf{1 0}$ & $\mathbf{1 9 . 2}$ \\
Below average & $\mathbf{8}$ & $\mathbf{1 5 . 4}$ \\
Not involved at all & $\mathbf{1 5}$ & $\mathbf{2 8 . 8}$ \\
\hline Total & $\mathbf{5 2}$ & $\mathbf{9 9 . 9}$ \\
\hline
\end{tabular}

From table 3 , it is clear that $44 \%$ of respondents say they are not as fully involved in deciding when they must go on training. While $28.8 \%$ say they are not consulted at all, $15.4 \%$ say they are hardly consulted. Many working adults would usually plan their work activities ahead. Planning for them to go on training must necessarily involve them so that they can make adequate time for training. An impromptu training may more or less find the trainee either being late for training sessions or leaving early because they have other commitments. Involving prospective trainees in planning when they should go on training is a good way of making them fully commit to attending the training without distractions.

Table 4 Summary of responses on factors accounting for employees' inability to transfer taught competencies into their work practice

\begin{tabular}{lll}
\hline Variables explored & Frequency & Percentage \\
Length of training too short & 21 & 40.38 \\
Time of training not convenient & 31 & 59.61 \\
Poor design and method of facilitation & 19 & 36.54 \\
Language difficult to understand & 5 & 09.62 \\
Poor facilitation & 17 & 32.69 \\
Program content not relevant & 23 & 44.23 \\
Lack of follow-up training programs & 36 & 69.23 \\
Lack of coaching and mentoring & 41 & 78.85 \\
Supervisors lack training in coaching and mentoring & 37 & 71.15 \\
\hline
\end{tabular}

Table 4 shows that respondents see the need for support after the attend training to ensure they fully master the competencies for improved performance. Also prominent are the need for follow-up programs, the need for their immediate supervisors to exercise their expected 
duty of mentoring and coaching them. All these can be achieved if organisations put in place proper employee appraisal systems.

Table 5 Summary of responses on the role of post-training coaching, mentoring and monitoring in the transfer of taught competencies into practice

\begin{tabular}{lll}
\hline Response & Frequency & Percentage \\
Strongly agree & 33 & 63.46 \\
Agree & 16 & 30.77 \\
Indecisive & 03 & 05.76 \\
Disagree & 00 & 0 \\
Strongly disagree & 00 & 0 \\
\hline Total & 52 & 99.9 \\
\hline
\end{tabular}

Table 5 indicates that approximately $94 \%$ of the respondents agreed that post-training coaching and mentoring is needed to ensure effective transfer of training. Their assertion confirms Friesen et al (2009) claim that transfer of training is not effective primarily due to lack of support systems to manage the transfer process. Management who want to see returns on the investment on training must ensure that structures are put in place to ensure the continuous and active use of skills and attitudes employees learn at training.

\section{Conclusion}

The study sought to find out reasons behind the seemingly inability of some employees to transfer competencies they acquire from training into their job performance and explored the role proper employee appraisal systems can play in ensuring that transfer of training is effective and the organization benefits from its investment on employee training. Results of the study have proved the importance of performance appraisal in ensuring the continued performance development of the employee by fully involving the employee in the identification of performance gaps, identification of appropriate training programs to address the gaps and the provision of follow-up support to ensure the effective transfer of training into practice.

\section{Recommendations}

1. The immediate manager and the entire members of the department of the trainee must be fully supportive of his training

2. Conscious efforts must be made to create opportunities for the trainee to practice the learned skill on the job. Work systems and processes must afford the trainee the opportunity to use the skill. In addition, efforts must be made to provide the necessary resources needed for the use of the skill.

3. Enough time must be devoted to the practice of the skill

4. Management must ensure that the trainee is retained at the job where he would practice the skill

5. Since old habits are difficult to change, planned efforts must be made to guide the transfer of habit.

6. A fair reward system must be instituted to support the successful mastery and demonstration of the use of the new skill.

\section{References}

[1] Allen Communications Learning Services (2015). What Is Employee Training and Development? Retrieved from www.allencomm.com.

[2] Andrew. (2016). Five Reasons Why Performance Appraisal is Essential. Retrieved from www.learnthat.com

[3] Archer North and Associates, (2010). Benefits of Appraisal. Retrieved from www.performanceappraisal.com 
Texila International Journal of Management

Volume 2, Issue 2, Dec 2016

[4] Atton, L., (2015). Three Ways to improve Transfer of Learning. Retrieved from www.business.com

[5] Bacal and Associates, (2015). Why Does Training Often Fail? Retrieved from performance.appraisals.org.

[6] Beardwell I., Holden L., (1997). Human Resource Management: A Contemporary Perspective. Prentice Hall. ISBN 10:0273622307

[7] Beer, M., Finnstrom, M., Schrader, D., (2016). Why Leadership Training Fails. Retrieved from https://hbr.org.

[8] Benton, B. (2014). Importance of Employee Training: 6 Reasons Why It Saves You Money. Retrieved from https://redshift.autodesk.com

[9] Bernardin, H. J., (2003). Human Resource Management: An Experiential Approach. New York McGraw Hill/Irwin

[10] Brunot, T., (2016). Importance of a Training Budget in Organizations. Retrieved from www.work.chron.com

[11] Enablingchange.co.uk, (2013). Why you should Continue Training and Development in the Workplace.

[12] Fleming, M., (2016). Why Training Fails: Check out the Top Reasons. Retrieved from www.hr.com

[13] Frieson, Kaye \& Associates, (2009). Training Transfer: A Corporate Strategy for Applying Skills \& Knowledge in the Workplace. Retrieved from www.fka.com

[14] Frost, S., (1995). The Importance of Training and Development in the Workplace. Retrieved from www.smallbusiness.chron.com

[15] Grove, A., (2007). High Output Management: Why Training is the Boss's Job. Retrieved from https://www.amazon.com

[16] Harrison, M., (2002). Human Resource Management: A practical approach: London, Thomson learning

[17] Healthfield, S. M., (2016). Everyone Wins: 4 Tips for Employee Training Transfer. Retrieved from https://www.thebalance.com

[18] Horowitze, B., Horowitze, A., (2010). Importance of Training. Retrieved from www.businessinsider,com

[19] Latham, A., (2013). Why Training Fails. Retrieved from https://www.td.org

[20] Mayhew, R., (1967). Importance of Employee Performance in Business Organizations. Retrieved from www.smallbusiness.com

[21] Mote, D., (2016). Performance Appraisal and Standards. Retrieved from www.referenceforbusiness.com

[22] Noe, R., (2005). Employee Training and Development. New York: McGraw- Hill/Irwin. Oakley;

[23] Philips, J., Philips, P. P., (2014). Eleven Reasons Why Training and Development Fails ... and what you can do about it. Retrieved from www.roiinstitute.net

[24] Puckett, J., (2015). The Importance of Performance Management. Retrieved from www.technologyadvice.com

[25] Sinha, R., (2007). Corporate Training - Why Training Programmes in Companies Fail. http:EzineArticles.com

[26] Spitzer, D. R., (1984). Why Training Fails. DOI: 10.1002/pfi.4150230704

[27] Sullivan, J., (2011). Increasing Employee Productivity: The Strategic Role that HREssentially Ignores. Retrieved from https://www.eremedia.com

[28] Tschol, J., (2014). 12 Reasons Why Employee Training Fails. Retrieved from www.callcenteriq.com 